Article

\title{
Implementation of the UN Convention on the Rights of Persons with Disabilities: A Comparison of Four European Countries with Regards to Assistive Technologies
}

\author{
Tanja Bratan ${ }^{1, *}$, Piret Fischer ${ }^{1}$, Maria Maia ${ }^{2} \mathbb{D}$ and Vera Aschmann ${ }^{3}$ \\ 1 Business Unit Innovations in the Health System, Fraunhofer Institute for Systems and Innovation \\ Research (ISI), 76139 Karlsruhe, Germany; piret.fischer@isi.fraunhofer.de \\ 2 Life, Innovation, Health, and Technology, Institute for Technology Assessment and Systems Analysis (ITAS), \\ Karlsruhe Institute of Technology (KIT), 76133 Karlsruhe, Germany; maria.maia@kit.edu \\ 3 Department of Chemistry and Life Sciences, Karlsruhe Institute of Technology (KIT), \\ 761312 Karlsruhe, Germany; vera.aschmann@student.kit.edu \\ * Correspondence: tanja.bratan@isi.fraunhofer.de
}

Received: 16 July 2020; Accepted: 10 September 2020; Published: 25 September 2020

check for updates

\begin{abstract}
The United Nations Convention on the Rights of Persons with Disabilities (CRPD) is an international treaty that aims to promote, protect and ensure the rights of persons with disabilities so that they can fully participate in society and enjoy the same freedoms and opportunities as others. It provides an important framework for the inclusion of persons with disabilities with the help of Assistive Technologies (AT). This paper assesses and compares the implementation of the CRPD with regards to the availability of AT in four countries (Germany, Hungary, Portugal and Sweden), which to some extent represent different European regions. The paper is based on a review of relevant academic literature, the DOTCOM database and regulatory documents as well as on five validation interviews with national experts. In the countries studied, anti-discriminatory and other legislation is included at the highest level of the legal framework and contains detailed rules on definitions, remedies and legal procedures. There are specific prohibitions in several fields, such as employment, housing, and healthcare. Nonetheless, there are still cases of non-compliance with the CRPD and of laws and regulations which discriminate against persons with a disability. Additionally, there are great variations between countries. As very positive examples of favourable regulatory frameworks for furthering inclusion with the help of ATs do exist, there may be benefit in raising awareness of such examples to support other countries in developing their own measures.
\end{abstract}

Keywords: CRPD; persons with disabilities; inclusion; regulatory environment; assistive technologies

\section{Introduction}

One key factor in measuring a society's degree of development is in how it deals with its members with disabilities and to what extent it strives and succeeds in including them in everyday life, education and employment, among others. Persons with disabilities are considered to be "those who have long-term physical, mental, intellectual or sensory impairments which in interaction with various barriers may hinder their full and effective participation in society on an equal basis with others" [1].

Discriminating against persons with disabilities has serious and damaging consequences for them as individuals $[2,3]$ as well as for society more generally as it deprives itself of the full contribution 
of a significant proportion of its population ${ }^{1}$. Assistive Technologies (ATs) play an important role in the inclusion of persons with disabilities as they can help to participate in everyday activities and promote independence. They can be defined by the application of organised knowledge and skills related to assistive products, including systems and services [4]. According to ISO standard 9999:2011, they are classified based on their function and include products and technologies for medical treatment, employment and training, personal care, mobility, housekeeping, furnishings and adaptations to homes, communication and information, recreation, as well as orthoses and prostheses among others.

The backbone of ensuring inclusion is the regulatory framework. It sets the rules for the inclusion of persons with disabilities and defines their rights in terms of not suffering discrimination and receiving the necessary support for living as independently as possible. While certain aspects of inclusion and non-discrimination are regulated at EU level, many lie within the competence of the Member States.

This article aims to provide an overview of the context within which ATs for persons with disabilities exist in Europe. For this purpose, the regulatory environment for the inclusion of persons with disabilities at EU level is described. The article focuses only on areas where the availability and use of ATs is particularly relevant, such as education, employment, independent living or mobility. A summary of the country comparison is provided in Appendix A. To capture the diversity of different European regions, Germany, Hungary, Portugal and Sweden are examined as cases at national level.

The United Nations Convention on the Rights of Persons with Disabilities (CRPD) was the first legally binding international human rights instrument to which both the EU and its Member States are parties. It was an important step in marking a paradigm shift in the way persons with disabilities are seen. Gradually, the perception has been moving away from viewing persons with disabilities as "objects" of charity, medical treatment and social welfare towards viewing them as "subjects" with rights and who can be active members of society if the right provisions are made [5]. Additionally, the CRPD has promoted the approach that when it comes to disabilities or impairments, the problem is not centered around the person, but rather the disabling barriers put up by society, which need to be removed to achieve inclusion [6].

The CRPD came into force on 3 May 2008, once it had been ratified by the twentieth party. Fifty specific articles and general principles build a comprehensive framework for the empowerment and non-discrimination of persons with a disability. The Convention also includes articles on monitoring and mechanisms for reporting on the progress of implementation. Most parties also signed the Optional Protocol, entitling the UN Committee on the Rights of Persons with Disabilities to monitor violations of the rights of persons with a disability [7].

\section{Materials and Methods}

The paper is based on a review of relevant academic literature, the Disability Online Tool of the Commission (DOTCOM) [8] and regulatory documents at national and European levels. DOTCOM is an information database about national laws, policies, strategies and initiatives in the European Member States, developed and maintained by the Academic Network of European Disability experts (ANED). It received funding from the European Commission until June 2019 and is currently suspended, pending a decision about further funding. Up-to-dateness of the information was verified. As DOTCOM is very comprehensive and this article makes extensive use of it, it is not referenced individually.

In addition, five semi-structured validation interviews (cf. Appendix B for the list of interviewees) with national experts, selected from the four countries, were carried out in order to compensate for language barriers and for cases of incomplete or out-of-date documents. These also proved useful in

1 It should be borne in mind that the majority of persons with a disability or impairment are elderly and have acquired their limitation as they have grown older. As the groups of persons with disability and elderly people often overlap, regulatory measures that are designed to support the rights of elderly people can benefit persons with disabilities and vice versa). 
gaining insights into the extent to which the regulation had been implemented and how successful it had actually been. Personal assessments of the national situations come from the national experts interviewed. The interviews were conducted between June and July 2016 using an interview guide (cf. Appendix C). With an average duration of 1 to $1.5 \mathrm{~h}$, they were recorded after interviewee consent and subsequently summarised in English for analysis.

\section{Results}

\subsection{Regulation at European Level}

\subsubsection{Regulation for the General Inclusion of People with Disabilities}

The implementation of CRPD-relevant law in Member States is monitored by the European Commission. The first official report of the EU on the implementation of the CRPD was published in 2014, while internal reports on policy for and the situation of persons with a disability are issued annually by the Disability High Level Group. The follow-up report, due in 2019, has not been published yet. Shadow reports to the first official report were submitted to the UN by a number of civil society organisations and advocacy organisations representing persons with a disability, for example the European Disability Forum.

Actions to be undertaken to achieve the rights of persons with a disability and to implement the CRPD are defined in the European Disability Strategy 2010-2020. The Strategy is a comprehensive framework committing the Commission to the empowerment of persons with disabilities to enjoy their full rights and to removing everyday barriers in their lives. It identifies eight areas of action; the most notable of these are an accessibility initiative (e.g., promoting the market for ATs), participation (e.g., web accessibility and mutual recognition of disability cards), funding (e.g., allocation of EU funds taking accessibility into account) and awareness-raising (e.g., European Award for accessible cities). The current strategy is coming to an end and is currently being evaluated with regards to its effectiveness, efficiency, relevance, coherence and benefits. The evaluation will be used to inform future policy developments [8].

The need for reliable data on the regulatory framework for persons with a disability in the EU and its Member States as a basis for policy development and implementation of the CRPD has been met by the Academic Network of European Disability experts (ANED) since 2007. The network was established by the European Commission, working together with existing disability research centres and national organisations. ANED set up the Disability Online Tool of the Commission (DOTCOM) in 2012, providing detailed information on policies, laws and strategies concerning the rights of persons with a disability and implementation of the CRPD in the EU, its Member States and associated countries. In addition, ANED regularly publishes reports on different topics concerning the situation of persons with a disability, for example statistical indicators, EU law and policy, employment or political participation. Funding was suspended in June 2019 and has not been renewed to date.

The non-discrimination of persons with disabilities is also embedded in key legal pillars of Europe. This includes the Charter of Fundamental Rights of the EU, which was proclaimed in 2000 and was required because the European Economic Community Treaty from 1958 did not make any references to fundamental human rights. It addresses equal rights for persons with a disability in several articles: Article 1 states that "human dignity is inviolable". Discrimination on various bases, including disability, is prohibited according to Article 21. Article 26 addresses inclusion and assistance for persons with a disability. The EU is obliged to respect the Charter of Fundamental Rights in all its activities.

The Treaty on the Functioning of the European Union addresses non-discrimination in Article 10, committing itself to mainstreaming the disability perspective, among others, in all policies and activities. The power to pass laws against discrimination on various bases, including disability, in all areas of EU competence is stipulated in Article 19 of the Treaty. 


\subsubsection{Regulation Concerning Specific Areas of Life}

Specific legislation promoting the rights of persons with a disability covers the areas of competence or shared competence of the EU. Some other areas are exclusively managed by the individual Member States, for example social security systems and education. However, the EU might influence these issues with position papers or by funding allocation (e.g., non-discrimination and respect for accessibility is required of all projects receiving EU funding).

One example of EU competence are European transport networks. For transport accessibility, there are four main EU regulations: the Air Passengers Rights Regulation (from 2006), two regulations on the rights of rail passengers (2007) and regulation concerning the rights of passengers when travelling by sea and inland waterway (2010). The main points of these regulations include protection from denial of boarding because of disability, provision of qualified assistance, accessibility of essential information and provision of a complaints mechanism. For the trans-European conventional rail network, a set of technical rules aim to ensure structural accessibility (e.g., wheelchair-accessible seats).

A second example of EU competence is the telecommunication sector and, to some extent, the media. The Audiovisual Media Services Directive includes an article encouraging Member States to adopt ICT accessibility legislation for people with a visual or hearing disability. The European Commission has issued two mandates to European Standardisation Organisations. The first addressed ICT accessibility for the elderly and persons with a disability on the basis of the principles "design for all" and "ATs" [9]. The second mandate called for EU standards on e-accessibility, which can be used in public procurement [10]. However, such mandates are recommendations rather than strict regulations. Concerning telecommunications, user rights are stipulated in the regulatory framework for electronic communications: The Users Rights Directive, for example, stipulates equal access for users with a disability to all services available to other end-users and encourages Member States to use European standards for e-accessibility. The EU also signed the Marrakesh Treaty—an agreement which aims for a higher availability and cross-country exchange of books and prints in accessible formats for the blind, visually impaired and otherwise print-disabled [11].

A third and very important area of European competence concerns the rights of persons with a disability in the labour market. The Employment Equality Directive was adopted in 2000 and prohibits discrimination regarding employment and occupation on various grounds, including disability. According to the directive, employers are obliged to provide reasonable accommodation for persons with a disability. The directive allows for positive action to prevent discrimination or for compensation for disadvantages experienced by persons with disabilities in the labour market.

\subsection{Comparison of the Level of Implementation and Operationalization of Key European Legislation in Germany, Hungary, Portugal and Sweden}

\subsubsection{Overview of Social Care Systems and Sociocultural Context}

The four countries under study not only differ in terms of location within Europe, size and economic performance, but also how social welfare is organised. A country's social care system is an important factor in the provision of ATs and the following sections give details on the chosen case studies. It should be noted that due to differences in counting, the number of persons with disabilities is not directly comparable between the countries.

In Germany, which has a population of 83 million people, roughly $9 \%$ of the population has a disability [12]. The German social security system is fairly comprehensive and consists of health insurance and long-term care insurance, among others. The needs of persons with a disability may be covered by different insurance systems. Rehabilitation and ATs, for example, can be provided either by the health insurance (in case of an acute medical condition), by the long-term care insurance (in case of long-term care) or by the accident insurance (if disability is due to an accident). It is not always clear which insurance system is responsible, which can lead to delays for people seeking support. Some disabilities are also addressed by specific laws: blind and deaf persons, for instance, receive a 
monthly sum according to the Assistance for Blind and Deaf Persons Law. In terms of the sociocultural context, inclusion of people with disabilities has not yet become fully ingrained in German society. In education, housing and employment, dual structures still exist, thereby separating certain persons with disabilities from mainstream society, especially those with psychosocial disabilities. The education system is also highly selective with its different levels of secondary education. The role of the family is less important than in other countries and people receive more support from the state, including ATs.

In Hungary, with a population of 9.8 million people, roughly $6 \%$ of the population are considered as living with a disability. The National Health Insurance Fund (NEAK) is free for persons with disabilities, including those with physical and mental disorders [13]. To receive a disability pension in Hungary, the insured person must fulfil a number of criteria, such as a loss of working capacity of at least $40 \%$ and incapability of any gainful employment. Depending on the disability, the monthly pension is between $30 \%$ and $150 \%$ of the monthly minimum wage [14]. The social security system in Hungary is still far behind Western European countries and Scandinavia, and is considered to be aligned with the overall level of economic development in the country. From a sociocultural perspective, Hungary still has a largely paternalistic approach towards persons with disabilities, with still too many people being placed under guardianship. They are more likely to be placed in institutions than supported in independent living or being looked after by their families. Under Prime Minister Viktor Orbán, financial support by the state has been reduced and NGOs are playing an important role in filling this void, also with regards to the provision of ATs.

In Portugal, counting 10.3 million people, about $18 \%$ of the population aged 5 or above reported having a lot of difficulty or being unable to perform daily activities such as seeing, hearing, moving around, etc. In the population aged 65 or above, this exceeds $50 \%$ [15]. In recent years, the collaboration of ministries responsible for social security has improved. Joint projects include an initiative to improve the continuity of long-term care for older people and people with disabilities [16]. The social welfare system for people with disabilities is fragmented and discriminatory and does not promote independent living. From a sociocultural perspective, due to the lack of a national personal assistance scheme, the system is based on the idea that families should provide for their relatives with disabilities and that they have a duty to support them, while the state only plays a supplementary role. In general, associated with poor education, prejudice and negative attitudes against persons with disabilities still prevail. This can be particularly noticeable when it comes to the employment of persons with a disability, since disability is still associated with a diminished efficiency and work quality. Disability is still assessed as a "medical" condition associated with a person, as opposed to a societal issue that affects both the able-bodied and persons with disabilities.

In Sweden, with about 10.2 million inhabitants, around 20\% are considered as having a disability, and around half of the persons with disabilities use ATs. Among the population with disabilities, $70 \%$ are 65 years old or older. The country provides universal healthcare for its citizens. Persons who have a permanent loss of functional capacity receive a disability allowance. Someone who requires daily assistance receives an assistance allowance. To be entitled to a disability allowance, the person must be categorised, for example, as suffering from a mental disability such as autism or suffering from physical disability that is not a normal consequence of ageing and that causes significant difficulties in the person's daily life (e.g., visual or hearing impairment). The overall situation of a person with a disability, the various forms of assistance required and the extra costs are all taken into account when determining the amount of the disability pension [17]. The sociocultural context in Sweden means that universalism and equality are of high priority. Inclusion is therefore a familiar concept and is supported by the state. The right of people with disabilities to independence is widely accepted and is supported both with ATs and personal assistance.

\subsubsection{Implementation of the UN Convention and National Focal Points}

The ratification of the CRPD requests the signatories to appoint a so-called "focal point" within their government structure. This role is usually fulfilled by one or more ministries and is supposed 
to concentrate all matters of disability rights in one institution in order to accelerate related actions in different government sectors and on all levels [18]. All four countries have appointed a specific ministry as an official focal point.

In Germany, it is the Federal Ministry for Labour and Social Affairs, with each federal state also having its own focal point, while in Hungary, the Ministry of Human Capacities has been assigned this role. However, in Hungary, the Office for the Secretary of State for Social Inclusion is responsible for disability affairs in general, thus including the CRPD. This shared responsibility aims to reflect the fact that improvements must be made in several fields simultaneously, which requires collaboration. In Portugal, responsibility is also shared: the Directorate General of Foreign Policy of the Ministry of Foreign Affairs and the Office of Strategy and Planning of the Ministry of Solidarity, Employment and Social Security have been appointed as focal point. In Sweden, the Family and Social Services Division of the Ministry of Health and Social Affairs is the official focal point.

\subsubsection{Coordination of Implementation}

Article 33 of the CRPD also stipulates that a coordinating mechanism needs to be implemented by each country. The purpose is to regulate projects, law-making processes and implementation. It should ideally include several responsible entities in order to ensure independence. Additionally, one or more "independent mechanisms" can be set up [18]. In Germany, the coordination mechanism consists of the Federal Government Commissioner for Matters Relating to Persons with Disabilities and the Advisory Council on Inclusion. It is supported by four specialist committees, which provide reports on various topics related to the CRPD. Furthermore, an independent Monitoring Body of the CRPD (independent mechanism) was established as a separate department at the German Institute for Human Rights.

In Hungary, a formal coordination mechanism was not established until 2015, when the inter-ministerial Committee on Disabilities was set up [19]. The National Council on Disability Affairs (NCD) fulfils the role of the independent mechanism. Within the NCD, a number of disabled people's organisations are represented. In Portugal, the National Institute for Rehabilitation, from the Ministry of Solidarity, Labour and Social Security, acts as a coordination mechanism at the governmental level. An independent mechanism has been set up and consists of ten members from different fields of expertise. Since the election of its chair in 2016, the Mechanism has met regularly and is active in the further implementation of the CRPD. In Sweden, the coordination mechanism is composed of representatives from different ministries, led by the Ministry of Health and Social Affairs, which also has the task of wider coordination of the work of the government on disability policy and is also the focal point as described above. An independent mechanism does not exist in Sweden.

\subsubsection{Reporting on Implementation Progress}

According to Article 35 of the UN CRPD, every country is expected to submit a report on progress toward implementing the convention within two years of it taking force. In addition to these official reports, advocacy organisations publish their own shadow reports.

Germany submitted its first official report in 2011. An alliance of non-governmental organisations submitted their own shadow report in 2013, as did the German Institute for Human Rights in 2015. In April 2014, the UN sent a "List of Issues" to the German government, which consisted of open questions on the state report. Among the questions were many focusing on the role of the German Federal States in the implementation of the CRPD. As the federal states are sovereign in education matters, they play an important role in inclusion of students with disabilities [20]. The German Government responded that almost all federal states had issued separate action plans for further inclusion of persons with disabilities [21]. Concluding observations on the first country report of Germany were published by the UN and included the urgent recommendation to develop a strategy to provide access to inclusive education across all federal states. Recently, the German Institute for Human Rights issued an analysis of the situation, stating that although efforts had been made, persons 
with a disability had still not achieved complete equality in terms of their rights. They also criticised double structures in education, housing and the workplace [22].

Hungary submitted its official report as one of the first countries in 2010 and again in 2017. The "List of Issues", published in 2012, focused, among others, on the support available for people with mental disabilities, the situation of Roma people with disabilities, the guardianship system and institutionalisation. A Hungarian Disability Caucus, consisting of several NGOs and the Ombudsman, was established in 2010 and soon after published a shadow report. The Caucus harshly criticised the government, finding praise only for the implementation of sign language interpretation. They reported on the Hungarian government not making sufficient efforts to ensure the standards of the Convention [23]. The UN's concluding observations from 2012 criticised Hungary's focus on impairment rather than the barriers persons with disabilities face, which is not compatible with the Convention. It also demanded for the definition of disability to encompass mental disabilities and for substitute decision-making to be replaced with supported decision-making.

In Portugal, the first state report, written by a Working Group of the National Human Rights Committee, was submitted in 2012. Reacting to the official report, the Disability and Human Rights Observatory and the Disabled People's Organizations that are members of its Advisory Board, in cooperation with a large number of civil society and disability organisations, submitted a shadow report in June 2015 [24]. In April 2016, the UN published an assessment report [25], where deep concerns were raised regarding the large number of persons with disabilities who were subjected to total or partial guardianship and, as such, deprived of certain rights. In the report, the revision of the existing regimes of full and partial guardianship was recommended. The report also suggests the development of systems for assisted decision-making. The Civil Code was being reviewed and the former guardianship model replaced in 2018 (see Section 3.3).

Sweden submitted its first official report in 2011. A shadow report by the Swedish disability movement was published soon after, calling on decision makers to plan society, activities and environments in a way that includes all citizens and that conforms to existing laws [26]. Several other shadow reports were also submitted. The UN Committee published Concluding Observations in 2014. They commended the country on the equality of the Swedish Sign Language with other minority languages and the right to vote and be elected for all persons with disabilities, including those with intellectual disabilities. Nevertheless, some aspects still needed improvement according to the Committee, e.g., that a new bill on non-discrimination in the workplace would not be applied to companies with fewer than ten employees. The next official report as well as the shadow report were submitted in 2019.

\subsection{Comparison of the General Legal Frameworks}

\subsubsection{Anti-Discrimination}

Article 5 (equality and non-discrimination) of the CRPD states that all persons are equal before the law and have the right to equal protection and equal benefit without any discrimination. In all four countries, legislation against discriminating people with disabilities, along with other possible causes of discrimination, is embedded in the constitution. These countries also have further acts prohibiting discrimination or stipulating equal treatment of persons with disabilities. Hungary, in addition, placed special emphasis on coordinated action regarding autism, as shown by their national autism strategy.

In Germany a ban on discrimination on the basis of disability was added to the German Constitution in 1994. In 2001, a separate legal code for rehabilitation and participation of persons with disabilities, the Social Code Book IX, was adopted. Among other things, it regulates benefits for persons with a disability in the areas of rehabilitation and work. In 2002, the Disability Equality Act took effect with the main goal of providing accessibility for persons with a disability. Protection from discrimination in the workplace and in civil law was given a legal basis in the General Equality Act in 2006. 
In Hungary, the general legal framework is very similar to that of Germany: the Fundamental Law bans discrimination and the Act on Equal Treatment and Promotion of Equal Opportunities (2003, amended in 2006) describes rules on anti-discrimination. Specific arrangements on equal treatment of persons with disabilities are made in the Equal Opportunities Act (1998). Furthermore, the Hungarian Parliament has approved a National Disability Program to establish measures for creating equal opportunities for persons with disability [18]. Hungary also is one of the very few states in the EU that has adopted autism plans and strategies. In Hungary, the 5-year National Autism Strategy (2008-2013) was initiated by the Ministry of Social Affairs and Labour and prepared by experts under the supervision of the Hungarian Autistic Society. The purpose of the strategy was to improve care for persons with autism by developing specific services, including those in the fields of education, training and employment [27].

Even though disability is not distinctly mentioned as a ground for discrimination in the Portuguese Constitution, the grounds listed are not considered to be comprehensive and are therefore usually assumed to also include disability. Article 71 of the Constitution affirms the equal rights of persons with disabilities, requiring the state to carry out a national policy of prevention, rehabilitation and integration. Two other legal documents have also addressed the prohibition of discrimination because of disability more recently: The 2004 Disability Act and the 2006 Anti-Discrimination Law. The latter defines discriminatory practices, for example, a lack of access to goods or services, the built environment, sign language, education, healthcare or information technologies.

In Sweden, the constitution states that all official bodies must treat all people equally and strive for full equality. The constitution also entitles all citizens to vote and to participate in politics without discrimination. The constitution further determines that the European Convention on Human Rights (ECHR) should have the status as constitutional Swedish law. The Discrimination Act of 2008 prohibits discrimination based on several grounds (among them disabilities). It is fairly comprehensive and covers areas such as the workforce, the education system and the possibility to buy and sell services and/or products, for instance, as well as national military service. It does not, however, mention access to civil and political participation.

\subsubsection{Guardianship and Supported Decision-Making}

Article 12 (equal recognition before the law) of the CRPD introduces the paradigm of universal legal capacity and the right to support for exercising this legal capacity. This includes the right to own and inherit property, to control financial affairs and to have access to all forms of financial credit. It means that all forms of substitute decision-making need to be revoked and therefore constitutes a highly important element of the CRPD. The approach to legal capacity differs greatly in the four countries studied and does not always fully comply with the CRPD. All countries have different levels of guardianship to reflect the capabilities of people in need of support. In Sweden, total guardianship has been abolished, and the basic assumption is that persons with disability are no different in terms of legal capacity from the rest of the population. Germany, Hungary and Portugal have also made the shift to supported decision-making.

In Germany, if a person is not able to manage their everyday life because of disability, a legal custodian can be appointed, according to the German Civil Code Book. The guardianship court determines the areas of agency for the custodian, depending on the person's condition. For certain far-reaching decisions, the legal custodian always needs the consent of the guardianship court, for example to abandon a rented home or for measures associated with the deprivation of liberty. In Germany, the institution of supported decision-making (Article 12 CRPD) has not yet been fully implemented into Civil Law. With the aim of better implementing the basic right of self-determination, preventive power of attorney (Vorsorgevollmacht) was established in the Civil Code Book in 2007. This legal action allows a person to appoint a proxy to act as their guardian in case they are unable to make decisions themselves. In an emergency, the guardian can act quickly without waiting for a court decision, however, more far-reaching actions such as admission to a secluded institution need a judge's approval. With the advance directive on care (Betreuungsverfügung), an instrument to determine aspects 
such as place of residence, choice of guardian and, to some extent, financial and medical preferences while still capable of such decisions, was established in 2009.

In Hungary, the general rules on legal capacity, guardianship and supported decision-making are regulated by the new Civil Code, which took force in March 2014 to achieve conformity with Article 12 of the CRPD. However, it did not abolish the guardianship system with an alternative based on trust and reciprocity. The new Labour Code states for example that people under partial guardianship are allowed to enter into a labour contract with the consent of their legal representative while people under plenary (i.e., full) guardianship can also enter into such contracts, but only their legal representative is entitled to make legal statements on their behalf. Both groups are allowed to enter employment contracts only for jobs which, considering their condition, they are capable of handling on a regular basis.

In Portugal, legal capacity is defined by the Civil Code as "the ability to enter a legal relationship". The majority of Portuguese citizens acquire legal capacity at the age of 18. The "Legal System of the Major Accompanied" was introduced by Law 49/2018, eliminating the previous regimes of inability and interdiction. The new regime aims to provide support to the person by enabling the full exercise of their rights. In the regime of adult support, an assistant, chosen by the person in need of support or their legal representative, provides assistance in decision-making processes.

Sweden already abolished total guardianship in 1989 [28]. A Memorandum of the Ministry of Health and Social Affairs states that persons with disabilities obviously have the same legal capacity as others. For persons with disabilities who require assistance, two alternative measures and less intrusive forms of assistance have been in place since January 1989. A trustee (förvaltare) can be appointed by the court as the person's guardian who does not need consent by the person with a disability to make a legally binding decision. In addition, a mentor (god man) system is implemented, which provides assistance to persons with a disability in legal and other matters. Since 2017, people have been able to write a special future letter of attorney (framtidsfullmakt) while still mentally able. The letter follows the principles of a will and is later used when the person loses their mental ability [29]. This is similar to the procedure in place in Germany.

\subsubsection{Voting}

According to Article 29 (participation in political and public life) of the CRPD, persons with disabilities should be able to exercise political rights on an equal basis with others. Article 3 (general principles) also applies as it states that persons with disabilities should not be discriminated against. Participating in political life allows them to have a political voice and contributes to their needs being politically represented. This, first of all, requires persons with disabilities to be allowed to vote, but also extends to voting procedures, facilities and materials being accessible as well as easy to understand and use. In terms of allowing persons with disabilities without full legal capacity to vote, the four countries differ in their approach and until recently the range was even greater. In 2018, Portugal abolished the legal "regime of interdiction" and introduced the "Legal System of the Major Accompanied" allowing the inclusion of more persons with disabilities in voting, while until 2019, Germany excluded those who have a guardian covering all areas of life. However, after a ruling of the Constitutional Court, the law was changed towards more inclusivity and also entitles voters with disabilities to support in voting. In Hungary, the right to vote is at least examined as part of the guardianship process. Only Sweden fulfils the requirements of the CRPD by granting persons with disabilities full voting rights. This is a central issue for equality and inclusion and should be used as an example in countries where voting rights are still restricted.

According to the constitutions of the four countries investigated, every person has the right to vote in general, direct, free, equal and secret elections.

In Germany, accessibility in elections is covered by the Disability Equality Act. Until 2019, according to the German Electoral Law, a person was deprived of the right to vote if they had a legal custodian covering all areas of life or if they had been sentenced to stay in a forensic institution because they committed a crime they could not be held responsible for. If the guardianship did not cover all areas of life, they were eligible to vote. The CRPD Monitoring Body criticised this practice in a 2017 
study, amongst other things pointing out that the ability to vote is not examined in the guardianship procedure and that plausible arguments for the denial of the right to vote were lacking. In February 2019, the German Federal Constitutional Court ruled that general exclusion of persons with disabilities under guardianship from voting is unconstitutional [30] and laws have been changed since. Polling stations are not always wheelchair accessible. Blind people can request to be sent a Braille voting template to use at the polling station or for voting by post.

In Hungary, the right to vote can be removed by a judicial decision on the grounds of restricted mental capacity (Fundamental Law, article 23). A court deciding on placing an individual under guardianship, specifically needs to consider the question of the deprivation from the right to vote (Act on the Electoral Procedure). Human Rights Watch has criticised Hungary for routinely excluding people with mental disabilities from exercising their right to vote. The European Court of Human Rights ruled in the case Alajos Kiss v. Hungary (2010) that there was a breach of Article 3 because the plaintiff had had his right to vote revoked when he was placed under partial guardianship. However, compliance with the CRPD has still not been implemented. Voters with disabilities who are eligible to vote can request notification in Braille and in simple language since 2014. Around half of polling stations were wheelchair-accessible in 2014 and each of the voting districts within every settlement is required to have at least one fully accessible polling station [31].

In Portugal, Article 2 of the Electoral Law specifies that citizens who have been assigned the status of interdiction, or persons with intellectual impairments under the regime of full or partial guardianship and those living in psychiatric institutions are unable to exercise their voting rights. However, with the introduction of the "Legal System of the Major Accompanied", the regime of interdiction was abolished, thus, people formerly "interdicted" regain their voting right (unless deemed "demented"). Article 97 of the Electoral Law entitles persons with visible physical disabilities or illnesses to be assisted at the voting booth by a person of their choice. Persons without visible disabilities are required to provide medical evidence in order to benefit from this. Although the Portuguese Electoral Law discriminates against persons with disabilities by compromising their right to free and secret vote, efforts are being made to change this. For instance, in the 2019 elections, a pilot test was made, for the first time using an electronic voting system. In addition, a grid in Braille, on top of the ballot paper, will also be used for the first time. However, it is still possible for a blind person to vote with the support of a third person, in case this is preferred.

Sweden guarantees the right to vote for all persons with disabilities, including those without legal capacity. The Swedish Election Act makes various provisions for persons with disabilities, including those who are unable to place the ballot in the envelope behind the voting screen being entitled to receive help from election officials. Persons with disabilities who cannot come to the polling station due to their disability, may vote through a "messenger". If the chosen voting premises do not fulfil the requirements for accessibility, officials need to explain the reason for their choice and what measures will be taken in order to offer accessible premises in future elections. The county administrative board (länsstyrelsen) then needs to decide if the premises in question can be used in the next election.

\subsubsection{Sign Language}

Sign language is covered in several CRPD articles, including Article 9 (accessibility), Article 21 (freedom of expression and opinion, access to information), Article 24 (education) and Article 30 (participation in cultural life, recreation, and sport), which illustrates its significance for inclusion. Recognition of national sign language as an official language has been accepted in all four countries under study, as early as in 1981 in Sweden and more recently (2009) in Hungary. In Portugal and Hungary, sign language is recognised by the constitution and in Germany and Sweden by separate acts. While this recognition by itself primarily has a symbolic character, it has important implications for the right to use sign language in different areas of life and to be provided with translation if necessary, therefore, it is important for inclusion and participation.

In Germany, the 2002 Disability Equality Act recognised German Sign Language as an official language. Users of the language are therefore entitled to the provision of a translator when they need 
to appear in front of public authorities (mentioned in Social Code Book IX). Children with hearing impairments can choose between bilingual and mainstream schools, although parents tend to prefer them to be schooled within the mainstream education system [32] and integrated education is generally being promoted.

Users of Hungarian Sign Language are legally considered members of a linguistic minority. Deaf and deaf-blind people are given the right to use special communication systems. Act 125 of 2009 also promotes users of sign language taking active part in society and participating equally in the political decision-making process. An important novelty of the Act is that the parent of a hearing-impaired or deaf-blind child may choose freely between a bilingual and a traditional auditive-verbal education method [18] and since 2017, bilingual education has been compulsory for deaf children in special schools. In Hungary, a particularly innovative approach to facilitating the use of sign language and other suitable forms of communication in everyday life is available and is worth mentioning. The Hungarian Association of the Deaf and Hard of Hearing has implemented a live "translation" service, offering voice, video and text message translation free of charge to registered users [33].

The Portuguese Constitution states that Portuguese Sign Language must be considered as a means of cultural expression and a tool for accessing education and facilitating equal opportunities. However, it is taught exclusively to deaf students; children without hearing impairments can only learn it in association with organised occasional activities. Portuguese Sign Language also features in the Anti-Discrimination Law, according to which denying access to sign language is defined as a discriminatory practice. The use of sign language interpreters is now allowed during training and practical examinations to obtain a driving license permit. Swedish Sign Language became the official language for hearing-impaired persons in Sweden in 1981, with the right to practice sign language. In the Swedish Language Act, it is established that people who need sign language must be given the opportunity to learn and use it. Children are expected to attend mainstream schools, and sign language is taught as an optional third language. For those who are unable to be schooled within the mainstream system, there are five regional special schools and three national special schools, each of which caters for pupils with different disabilities [34].

\subsection{Comparison of Regulation Concerning Specific Areas of Life}

\subsubsection{Regulation Concerning Public Spaces}

Access to public spaces is regulated in the following CRPD articles: Article 9 (accessibility), Article 29 (participation in political and public life) and Article 30 (participation in cultural life, recreation, leisure and sport). Accessibility of buildings open to the public, whether privately or publicly operated, is stipulated by acts in Hungary, Portugal and Sweden, while in Germany, this regulation only applies to publicly operated buildings. Except for Sweden, the implementation of accessibility still appears to be a challenge, thereby posing serious barriers for the full participation and inclusion of persons with disabilities. Sweden has promoted accessibility since the late 1970s and has therefore benefitted from a longer timeframe to successfully implement it.

In Germany, accessibility of public transport and public buildings was made a requirement by the Disability Equality Act (2002). Institutions can be fined for non-compliance. However, this does not apply to private buildings that are accessible to the public. The Disability Equality Act also applies to transport and stipulates that at the national level transport needs to be accessible. Full accessibility of public transport for persons with reduced mobility or sensory impairment needs to be accomplished by 2022 according to the 2013 Passenger Transport Act. Public transport is also mentioned in the Social Code Book IX, stipulating that persons with a recognised severe disability or who are blind or deaf are entitled to use public transport free of charge. The Disability Equality Act was amended in 2016 to include a more individualised approach to what is required for accessibility and the requirement that accessibility also be provided for non-large-scale building projects [35]. Overall, progress has been 
slower than expected and there is a certain focus on wheelchair accessibility with less consideration given to accessibility for visually impaired people, for example.

In Hungary, the Equal Opportunities Act (1998) requires all public service buildings to be accessible. This also applies to private buildings open to the public, whether old or new. The Equal Treatment Act (2003) can be applied for legal procedures in case of any breaches. Transport providers are also required to provide accessibility for persons with disabilities, which applies to all forms of public transport. Initially, a deadline was set for the latter in 2013 but it was later deleted by an amendment. In general, implementation in both buildings and transport has been slow due to a lack of resources.

In Portugal, the Disability Act (2004) stipulates the right of persons with disabilities to access transport, including the use of public transport. The law requires that public buildings and public-use facilities be made accessible. The National Plan for the Promotion of Accessibility (2007) established a set of measures to remove barriers to accessibility in transportation and the built environment, in workplaces, housing and ICT, to be set in 2007-2010 and 2011-2015; however, the second phase of the plan never started. In 2013, a new law amended the Road Code (Código da Estrada) by introducing a legal definition of "vulnerable users", which includes persons with reduced mobility (persons with a disability, children, elderly, pedestrians, etc.) to circulate in areas of the road specially marked for shared use by pedestrians and vehicles (designated as zones of co-existence).

In Sweden, the Special Transport Act of 1979 and the Special Transport Regulation of 1980 enacted the right of access to public transport for persons with disabilities. The efforts appear to have been quite successful, with $92 \%$ of Sweden's public transport having dedicated wheelchair spaces, $90 \%$ being equipped with a ramp or lift, and $76 \%$ having audio-visual announcements [36]. Various general rules for the physical environment were drawn up by the Planning and Building Act of 2010. It specified that in built-up areas, the environment needs to be adapted to accommodate the requirements of people with disabilities. This applies to both public and private buildings.

\subsubsection{Information and Communication Technologies (ICT)}

Article 21 (freedom of expression and opinion, and access to information) of the CRPD stipulates that persons with disabilities need to be able to freely seek, receive and impart information and ideas with others, including through electronic means. According to Chadwick and Wesson [37], digital inclusion is of increasing importance, as the use of digital technologies has become an essential aspect of most people's lives. It can also serve as a measure of human rights, equity and participation. ATs are of particular importance for people with visual impairments. However, none of the four countries studied can serve as a prime example of ICT accessibility. Overall, implementation levels across Europe are low despite policy efforts [38]. As these focus mainly on public sector websites, the majority of websites are not included and private providers do not appear to voluntarily follow the requirements set out for the public sector.

In Germany, the Disability Equality Act of 2002 provides the basis for ICT accessibility. It requires the public sector to ensure its websites are accessible. This includes interoperability with ATs and the provision of information in German Sign Language. Consequently, other changes have been made, for example in the Telecommunications Act (Telekommunikationsgesetz), which mandates that persons with disabilities must have equal access to broadcasting and telecommunication devices and systems. Privately operated websites are not obliged to make their content accessible. Instead, target agreements between website operators and disability associations are being used to create commitment.

While in Hungary ICTs and websites are not subject to the Equal Opportunities Act, the Provision on Accessibility of Information stipulates that they need to be accessible for persons with disabilities. Sanctions are possible for breaching this obligation (e.g., by the Equal Treatment Act). Government Decree 305/2005 applies to websites providing information of public interest. These websites are required to be accessible for visually impaired and blind people.

In Portugal, the Action Plan for Information Society demands that ICT and websites be accessible. Accessibility is also promoted through the National Programme for the Participation of Citizens with 
Special Needs in the Information Society. The measures proposed include increasing the accessibility of television channels and offering training on internet skills to persons with a disability. A new decree-law (83/2018) entered into force in January 2019, which regulates the accessibility of the public sector's websites and mobile applications that have to be made accessible to users, especially persons with disabilities.

In Sweden, information and activities related to the government must be accessible to persons with disabilities by law. There is no such obligation for municipalities. Additionally, a person with a disability is not entitled to receive information from government or municipal authorities in an accessible format of their choice.

\subsubsection{Independent Living}

CRPD Article 19 (living independently and being included in the community) recognises the equal right of all persons with disabilities to live in the community and for them to be provided with effective and appropriate measures to fully enjoy this right. Independent living constitutes a crucial element of freedom and human rights. In all countries under study, independent living is promoted as preferable to institutionalised care. While Germany provides a relatively adequate amount of funding, divided responsibilities can lead to delays in granting the support needed. In Hungary, ATs provided by the state are of low quality, which is why NGOs play a major role. However, ensuring equal access this way is very difficult. Portugal still relies heavily on the support of the families of persons with disabilities in terms of looking after them at home, and access to ATs is lengthy and bureaucratic.

In Germany, community-oriented assistance and care is a basic principle of the social security system and of long-term care insurance. According to the Social Code Book XII, persons with a disability can receive integration support. Blind and deaf persons are entitled to receive a monthly sum on the basis of the Assistance for Blind and Deaf Persons Law. ATs are available on prescription if they are listed in the health insurance benefits catalogue. Funding for the adaptation of houses is also available. All people who have been assigned to one of five care levels (Pflegegrade) are entitled to financial assistance and payments in kind. However, it is not always immediately clear which insurance system is responsible, and time and resources can be lost in the process of determining this.

In Hungary, independent living is supported by personal assistance (social) services. Several forms of allowance in kind are available from the government. However, conditions of entitlement and administrative processes are complex, ATs provided by the state are very basic and there is very little official information available in Hungarian. Therefore, assistive equipment for independent living, as well as information and services, are mostly provided by NGOs.

In Portugal, persons with disabilities traditionally live with their families, except in the case of mental disabilities. The 2004 Disability Act calls on the state to take the necessary measures to ensure adequate housing for persons with disabilities. Nevertheless, persons with disabilities can be obliged to live in a residential facility if they participate in education, training or other activities located in an area far from their home or if the family cannot guarantee proper accommodation. In 2010, a new decree-law established new types of services, aiming to provide community care for persons with psychosocial disabilities, thus reducing institutionalisation. The 2004 Disability Act states that the provision of appropriate means of compensation for persons with disabilities is the state's responsibility to improve autonomy and adequate integration into the community. The National System for the Ascription of Assistive Devices operationalises the act. Persons with an incapacity level of $60 \%$ or more can have free access to ATs. However, the process of obtaining them is lengthy and bureaucratic.

Sweden has a long history of de-institutionalising persons with disabilities, ranging back to the 1970s. According to the Swedish Law on Grants for Housing Adaptation of 1992, municipalities fund the adaptation of houses to enable people with functional impairments to keep living in their own homes. According to the Code of Social Insurance, persons with disabilities can apply for tax-free credit to cover specific additional costs of living. According to the Social Service Act of 2001, a prescription by a healthcare professional is required to obtain ATs. 


\subsubsection{Education}

Article 24 of the CRPD (education) recognises the right of children and young persons with disabilities to inclusive education. Not only can it prepare them better for participation in society and reaching their potential, but it also helps students without disabilities to develop valuable skills. Among others, this requires ATs to compensate for impairments. A commitment to inclusive education has been made by all four countries but only Portugal has closed special education schools altogether. Furthermore, a lack of funding can get in the way of providing ATs and trained staff, and economically more advanced countries appear to fare better in implementing the regulation. In higher education, the situation is more varied. While in Germany and Hungary universities are obliged to provide special support to students with disabilities, in Portugal this is only suggested on a voluntary basis. Overall, Article 24 has not been satisfactorily implemented yet.

In Germany, the constitution does not explicitly entitle children with disabilities to schooling in mainstream schools, but Article 3 forbids discrimination because of disability. Beyond this, school and university education are the sole responsibility of the 16 federal states and each state has its own legislation and school authorities. In the majority of states, integrative schooling is seen as the preferred option. There is a slight difference between states, with the northern states offering more opportunities for children with disability to be schooled in mainstream schools. Regarding university education, the national Framework Act on Higher Education (Hochschulrahmengesetz) requires universities to ensure that students with disabilities are given access to all academic courses and services, receive need-based special support in order to take exams and, in general, do not suffer discrimination.

In Hungary, the Act on National Public Education (2011) regulates the choice for children with disabilities between education in special schools and regular schools. However, in general, the education system for persons with disabilities in Hungary is lagging behind that of Western European countries. Many schools have serious infrastructure and accessibility problems. In university education, the National Higher Education Act grants students with disabilities special rights, such as special arrangements during examinations (e.g., use of ATs), extra time, the exemption from being assessed altogether and other exemptions.

In Portugal, the Disability Act (2004) states the right of persons with disabilities to education. Decree-law 3/2008, amended by Law 21/2008, led to the closure of special education schools and the integration of children with disabilities into regular schools. In 2018, the government issued and updated legislation (Decree-law 54/2018) aiming to strengthen inclusive education, by, among other things, recognizing the right to choose a school and by giving priority to the enrolment of children with disabilities. Schools funded by the Ministry of Education are required to provide education for children with disabilities since they are subject to the principle of non-discrimination on the grounds of disability. The same decree also foresees the existence of "reference schools", which are public mainstream schools where Braille or sign language can be learnt from preschool until the end of compulsory education. Universities are not subject to any legislation imposing obligations towards students with disabilities, other than the Anti-Discrimination Act which prohibits discrimination in all areas of life, including education. Legislation that regulates the national application process to higher education has established a $2 \%$ access quota for students with physical and sensory impairments. Another new decree-law from 2018, states that all children are entitled to the same education, and therefore students with disabilities need to transition smoothly between educational levels through a set of accommodations, as well as individualised educational programmes and an Individual Transition Plan.

In Sweden, all children must have access to an equal quality of education according to the Discrimination Act. According to Swedish School Law, children who cannot meet the requirements of regular schools are admitted to a special needs school (grundsärskolan). Local municipalities are in charge of compulsory schools for pupils with learning difficulties and, as in Germany, this is not regulated at federal level. At the higher education level, all universities and other institutions are required to establish a contact person or coordinator dealing with issues related to support for students 
with disabilities. Services that are typically available include sign language courses and translation, as well as books in Braille.

\subsubsection{Employment}

CRPD Article 27 (work and employment) grants persons with disabilities equal rights and opportunities at work. This is another important pillar of inclusion and also often requires ATs as an enabler. Discrimination regarding employment is prohibited in all four countries. To motivate employers to hire staff with disabilities, tax allowances and financial incentives are available in Hungary and Portugal. In Germany and Portugal, fines can be imposed for not meeting employment quotas, which includes both public and private employers. Hungary places a special focus on autism and provides funds for it through its National Reform Programme, in terms of which it is ahead of the other countries in utilising the capabilities of autistic people.

In Germany, persons with a disability are protected against discrimination in working life by the General Equality Act and Social Code Book IX. The latter requires all private companies and public services with 20 or more employees to have at least $5 \%$ staff who are severely disabled $(6 \%$ in case of private companies). Otherwise, a compensational tax applies, which is used for example to finance accessible workplaces. The employer is required to facilitate the adaptation of the workplace within the scope of what is deemed reasonable and has to consider the health and abilities of employees with disabilities, their tasks and responsibilities. State subsidies for workplace adaptation, adaptive technologies and personal assistance are guaranteed. All of these are available on a competitive basis every year until the funds are exhausted. In 2010, a Labour Court ruled that, up to an extent, an employer must enable remote work if the employee's disability keeps them from working at the regular workplace [39].

Furthermore, in Hungary, legislation on non-discrimination at the workplace is in place through the Equal Treatment Act (2003). The National Disability Programme also provides information on how to increase the rate of employment of persons with disabilities [19]. Guaranteed state subsidies for workplace adaptation, ATs and personal assistance are available; these are awarded on a competitive basis every year until funding is exhausted. According to a 2018 case study by Hungarian political science workshop Policy Agenda, employers' organisations have started to reach out and accommodate persons with disabilities as the working age population is predicted to decrease dramatically [40]. Financial incentives for companies to employ people with disabilities include tax allowances. Hungary is one of the few countries to have had a National Autism Strategy (2008-2013), which provided special services to people on the autism spectrum, including for employment [27].

In Portugal, the Disability Act (2004) announced the "right to employment, work and training". The Labour Code guarantees the right of employees and applicants to not be discriminated against regardless of characteristics such as disability, reduced working capacity or chronic disease. Within public administration, a quota of 5\% for external admissions was established in 2001. Mandatory quotas exist: $5 \%$ for public services external admissions (Decree-law 29/2001) and 2\% for people with an incapacity level of or over $60 \%$ in private sector companies with more than 75 employees (Law 4/2019). To prevent discrimination in the workplace, "reasonable accommodation" is fostered by the work developed by the Vocational Training Centres and by the provision of funds for workplace adaptations, elimination of architectural barriers, wages and social security contributions (in both public and private sectors) provided by the Institute of Employment and Vocational Training (IEFP, I.P.)

In Sweden, the Discrimination Act of 2008 covers all aspects of employment. Support at the workplace in the form of ATs or physical adaptation can be provided up to a certain amount, either through the county governments or through the municipalities. Personal assistance is available to those who need it to communicate, leave their home, etc. Employers who hire people whose work capacity is limited (for example due to disability) are sometimes entitled to wage subsidies [36]. 


\section{Discussion}

Our research has identified a number of positive examples and good practices, as well as difficulties and bottlenecks in the implementation of the CRPD in Germany, Hungary, Portugal and Sweden that affect the availability of AT. We have also taken a closer look at some of the more general framework conditions that appear to have either a positive or negative influence on the overall situation of persons with a disability in the four countries under study. Different options for future policy making can be deduced.

\subsection{Options for Future Policy Making}

One of the main difficulties for policy makers regarding the overall national level process of implementing the CRPD is the lack of precise and robust indicators that would allow measuring the actual impact and benefit of this Convention on a national level in and across different countries. The DOTCOM database already includes a number of indicators and sources and provides a comprehensive overview of the CRPD uptake process in the countries which have signed the Convention. If funding is extended, the same database could be developed further to also include reporting on respective indicators, which would enable policy makers to evaluate and compare the success of CRPD implementation better and to identify the actual success of particular policy measures.

Another possible step to improve the evidence base is the inclusion of more disability organisations in the national official reporting process, as is already the case in Sweden. Currently, shadow reports are published by disability organisations who feel that they cannot make their voices heard in the official reporting process.

Non-compliance with the CRPD is still a major issue. Where European directives have not been correctly implemented into national law, the European Commission can start a so-called "infringement procedure" and, as a matter of last resort, take the case to the European Court of Justice in Luxembourg [41]. Examples of infringement procedures already put into practice are, for instance, related to the transposing of the Web Accessibility Directive into national laws [42]. The enforcement of national legislation is up to the countries concerned. Due to the lack of compliance with the CRPD in several areas, stricter enforcement should perhaps be sought. In terms of guardianship, for example, unnecessarily limiting the rights of persons with disabilities and taking away their right to participate in the political process through voting are in breach of the CRPD. Indeed, Article 12 (equal recognition before the law) is considered a "central provision of the Convention" [43]. Action to eliminate such discriminatory practices is therefore urgently recommended.

In this context, recent changes to the Peruvian legal code have been highlighted as a positive example of full compliance with the CRPD, making this a good practice example for the countries in the study to follow. Since 2018, persons with disabilities in Peru have been enjoying full legal capacity. This is based on a flexible support model, with the support being chosen by the person who requires it. Underlying is not the "best interest" of that person but rather their ability to exercise their own will [43].

Binding requirements, for example regarding measures to improve the accessibility of ICT in the public sector, appear to be the most successful and could be extended to the private sector and other fields. Furthermore, reasons for non-compliance could be investigated and technical and other solutions developed that make it easier to develop accessible websites. Especially with IT-literate generations progressing into old age and continuing to rely on ICT, this will become an increasingly competitive factor in the future. To promote independent living, policies enabling and honouring family involvement while not making it a necessity, as is the case of Germany, might be a good way forward for persons with disabilities being able to choose how they want to live. Concerted national efforts to promote education and employment, especially focusing on mental disabilities, could contribute to reducing the stigmatisation and exclusion of a significant proportion of persons with disabilities. 
Finally, there are a number of problems afflicting ATs in each of the countries examined. The first major issue is heterogeneity. Within a country, persons with disabilities may be afforded different degrees of access to ATs and services, depending on where they live, which is often referred to as a "postcode lottery". This issue is especially evident in Hungary, Portugal and Sweden and less so in Germany. Another hindrance is a very long and bureaucratic process for obtaining ATs in general. Information on ATs is also not always easily available, putting people who are unaware of what is available and what they are entitled to at a disadvantage. Efforts could therefore be made to ensure that information and access to ATs is equal across individual countries and throughout Europe, as it is a key enabler of inclusion.

\subsection{Open Questions}

A number of open questions arise from our analysis. In Europe, the majority of social care and healthcare systems are funded through taxes. It remains to be seen how the quality of healthcare services can be maintained while facing current demographic trends, such as aging societies and an increasing number of people with disabilities on the one hand, and on the other, the increasing availability of expensive innovative ATs.

Secondly, we witnessed a general policy trend towards supporting and encouraging persons with disabilities to pursue a life as independent as possible, e.g., in terms of living in private accommodation instead of staying in large institutions and in terms of inclusive schooling and employment. However, questions arise as to how well these trends can be applied in practice, especially in countries where there are fewer resources available for individual support and assistance. For example, making provisions for students with different disabilities to be taught in most mainstream schools can be more costly than only equipping a small number of specialised schools with the necessary tools and resources.

Thirdly, this study did not investigate how well countries other than Hungary, Germany, Portugal and Sweden have adapted their legislation and regulations to better meet the needs of their citizens with disabilities. Further studies of a larger number of countries are necessary in order to determine whether more common patterns emerge and which European-level policy incentives could be designed to better meet the needs of persons with disabilities in different EU Member States.

\section{Conclusions}

Since the adoption of the UN Convention for the Rights of Persons with Disabilities in 2006, there has been an emergence of a new generation of human rights guarantees for persons with different disabilities that also affect the provision of ATs. Our findings indicate that the four countries under study have mostly successfully adopted the CRPD. In all four countries, anti-discriminatory and other legislation for the inclusion of persons with disabilities has been included at the highest level of the legal framework and contains detailed rules on definitions, remedies and legal procedures. There are specific prohibitions in several fields, such as employment, housing and healthcare. Nonetheless, there are still cases of non-compliance with the CRPD and of laws and regulations which discriminate against people with disabilities. There are also major variations between countries. For example, Sweden has taken the approach that persons with disabilities possess full legal capacity and if necessary are supported in decision-making, whereas in Portugal and Germany, only recent changes in legislation have allowed for such rights. In Hungary, full legal capacity is not guaranteed. Furthermore, the right to inclusive education has not been fully implemented in any of the countries except Portugal, where special needs schools have been closed. However, even in Portugal, mainstream schools would require adequate funding to become fully inclusive. These are serious violations of the CRPD and should be addressed with the highest priority.

Even where the legal system complies with the CRPD, there are major gaps in everyday practice, sometimes linked with a lack of enforcement of the legislation. In addition, significant variations within and between countries could be observed. 
All four countries have set up specific coordination and monitoring bodies and mechanisms ${ }^{2}$ (Hungary is an exception since it has not nominated a specific coordination entity on the Convention issues, although it nevertheless has a monitoring body in place). However, the submission of shadow reports by individual NGOs indicates that there may still be an unmet need for greater general involvement of NGOs in the official reporting process to the United Nations, as these NGOs consider it necessary to make their views heard through shadow reports. Greater involvement would make it possible for the majority of the criticism expressed in their shadow reports to already be included in the official reporting process.

While the adoption of legislation to comply with the CRPD is being monitored and also needs to be reported, evidence on the actual success of the measures is comparatively sparse. In particular, the definition of indicators that allow tracking the effects over time and across countries is missing, which makes it difficult to identify examples of particularly effective regulation. The good practice examples suggested here need to be considered within these methodological constraints.

In general, the move away from a "one-size-fits-all" approach towards a more individual one, taking into account the wishes and abilities of people with disabilities and viewing them as valuable members of society, is evident in various pieces of legislation and is likely to become increasingly prominent in the future. However, conservative attitudes, on the rise for example in Hungary, can counter this trend. In general, the sociocultural context of a country has a significant effect on how inclusion of persons with disabilities is developing. Sweden, with its liberal attitude and focus on equality, can be seen as a particularly positive example.

A problem present in all countries, which also has an impact on the availability and usability of ATs, is that the alignment between the regulatory measures in place and their implementation in practice is sometimes poor. Germany and Sweden seem to have a more decentralised and flexible policy framework to better address the requirements of persons with different disabilities, as well as the needs of the individual. Although the legal framework is mostly also fairly well adapted in Hungary and Portugal, the lack of resources seems to be a hindrance in keeping the state from playing a stronger role in arranging suitable living conditions and a better integration of people with disabilities into society. In Hungary, ATs are mainly provided by NGOs and the budget available is a fixed amount. In Portugal, very little public funding is available for ATs, and persons with disabilities and their families are expected to cover the costs. In Sweden and Germany, on the other hand, financial resources dedicated to ATs are not limited per person, but dependent on the needs of the individual.

Overall, there are already very positive examples of favourable regulatory frameworks for furthering inclusion with the help of ATs in different countries. There may be benefits in raising awareness of such examples to support other countries in developing their own measures.

Author Contributions: Conceptualization, T.B.; methodology, T.B.; formal analysis, T.B., M.M., P.F. and V.A.; investigation, T.B., M.M., P.F. and V.A.; writing-original draft preparation, T.B., M.M. and V.A.; writing-review and editing, T.B. and M.M.; project administration, T.B.; funding acquisition, T.B. and M.M. All authors have read and agreed to the published version of the manuscript.

Funding: This research was funded by the European Parliament's Panel for the Future of Science and Technology (STOA).

Acknowledgments: The authors would like to thank Linda Nierling for feedback on the content of this article. We would also like to thank the reviewers for valuable improvements and suggestions.

Conflicts of Interest: The authors declare no conflict of interest.

2 Hungary is an exception since it has not nominated a specific coordination entity on the Convention issues, although it nevertheless has a monitoring body in place. 


\section{Appendix A}

Table A1. Summary of Country Comparison.

\begin{tabular}{|c|c|c|c|c|}
\hline & Germany & Hungary & Portugal & Sweden \\
\hline $\begin{array}{l}\text { Responsibility for CRPD } \\
\text { implementation (national } \\
\text { focus points) }\end{array}$ & $\begin{array}{l}\text { Federal Ministry for Labour and } \\
\text { Social Affairs; additionally, each } \\
\text { federal state has its own focal point. }\end{array}$ & $\begin{array}{l}\text { Ministry of Human Capacities, } \\
\text { Office for the Secretary of State for } \\
\text { Social Inclusion (joint responsibility) }\end{array}$ & $\begin{array}{l}\text { Directorate General of Foreign } \\
\text { Policy of the Ministry of Foreign } \\
\text { Affairs, Office of Strategy and } \\
\text { Planning of the Ministry of } \\
\text { Solidarity, Employment and Social } \\
\text { Security (joint responsibility) }\end{array}$ & $\begin{array}{l}\text { Family and Social Services Division of } \\
\text { the Ministry of Health and Social Affairs }\end{array}$ \\
\hline Coordination mechanism & $\begin{array}{l}\text { Federal Government Commissioner } \\
\text { for Matters Relating to Persons with } \\
\text { Disabilities and the Advisory } \\
\text { Council on Inclusion }\end{array}$ & Committee on Disabilities & $\begin{array}{l}\text { National Institute for Rehabilitation } \\
\text { (part of the Ministry of Solidarity, } \\
\text { Labour and Social Security) }\end{array}$ & $\begin{array}{l}\text { Representatives from different } \\
\text { ministries, led by the Ministry of Health } \\
\text { and Social Affairs }\end{array}$ \\
\hline Independent mechanism & German Institute for Human Rights & $\begin{array}{l}\text { National Council on } \\
\text { Disability Affairs }\end{array}$ & $\begin{array}{l}\text { Ten members from different fields } \\
\text { of expertise }\end{array}$ & $\begin{array}{l}\text { None, as representatives from civil } \\
\text { society are included in the coordination } \\
\text { mechanism }\end{array}$ \\
\hline $\begin{array}{l}\text { Reporting_-Selected issues } \\
\text { identified }\end{array}$ & $\begin{array}{l}\text { Special facilities for persons with } \\
\text { disabilities in education, housing } \\
\text { and the workplace, heterogeneity } \\
\text { with regards to inclusive education } \\
\text { across federal states. }\end{array}$ & $\begin{array}{l}\text { Lack of support available for people } \\
\text { with mental disabilities, the } \\
\text { situation of Roma people with } \\
\text { disabilities, the guardianship } \\
\text { system and institutionalisation. }\end{array}$ & $\begin{array}{l}\text { Number of persons with disabilities } \\
\text { who were subjected to total or } \\
\text { partial guardianship. This has since } \\
\text { been addressed. }\end{array}$ & $\begin{array}{l}\text { Mostly positive, e.g., equality of } \\
\text { Swedish Sign Language with other } \\
\text { minority languages, as well as the right } \\
\text { to vote and be elected. Criticism } \\
\text { regarding bill on non-discrimination in } \\
\text { the workplace not applicable to } \\
\text { companies with } 10 \text { employees or fewer. }\end{array}$ \\
\hline Anti-discrimination & Constitution, additional acts & Fundamental Law, additional acts & Constitution, additional acts & Constitution, additional acts \\
\hline $\begin{array}{l}\text { Guardianship and supported } \\
\text { decision-making }\end{array}$ & $\begin{array}{l}\text { Guardianship system with } \\
\text { individual specification of } \\
\text { areas covered }\end{array}$ & Partial and full guardianship system & $\begin{array}{l}\text { Support through chosen assistant to } \\
\text { help decision-making ( } 2018 \text { change } \\
\text { from guardianship system) }\end{array}$ & $\begin{array}{l}\text { Trustee and mentor system, } \\
\text { guardianship abolished in } 1989\end{array}$ \\
\hline Voting & $\begin{array}{c}\text { Since } 2019 \text { people under } \\
\text { guardianship have been allowed to } \\
\text { vote }\end{array}$ & $\begin{array}{l}\text { Courts deciding on guardianship } \\
\text { can remove the right to vote }\end{array}$ & $\begin{array}{l}\text { Since 2019, people can vote with the } \\
\text { help of their assistants (except those } \\
\text { with dementia) }\end{array}$ & $\begin{array}{l}\text { Voting possible for all people, including } \\
\text { those without legal capacity }\end{array}$ \\
\hline Sign language & Status as official language & $\begin{array}{l}\text { Users considered a linguistic } \\
\text { minority with specific rights }\end{array}$ & $\begin{array}{l}\text { Considered as a means of cultural } \\
\text { expression and tool for equal } \\
\text { opportunities }\end{array}$ & Status as official language \\
\hline
\end{tabular}


Table A1. Cont.

\begin{tabular}{|c|c|c|c|c|}
\hline & Germany & Hungary & Portugal & Sweden \\
\hline Accessibility of public spaces & $\begin{array}{l}\text { Required for public transport and } \\
\text { public but not privately owned } \\
\text { buildings, implementation slower } \\
\text { than expected }\end{array}$ & $\begin{array}{l}\text { Required for public transport and } \\
\text { public service buildings regardless } \\
\text { of ownership; implementation } \\
\text { is slow. }\end{array}$ & $\begin{array}{l}\text { Required for public transport and } \\
\text { public service buildings regardless } \\
\text { of ownership, implementation } \\
\text { is slow. }\end{array}$ & $\begin{array}{l}\text { Required for public transport and public } \\
\text { as well as private buildings; } \\
\text { implementation is advanced. }\end{array}$ \\
\hline $\begin{array}{l}\text { Accessibility of information and } \\
\text { communication technologies }\end{array}$ & Required for public sector websites & $\begin{array}{l}\text { Required for websites providing } \\
\text { information of public interest }\end{array}$ & $\begin{array}{l}\text { Required for public sector websites } \\
\text { and apps }\end{array}$ & $\begin{array}{l}\text { Required for information related to the } \\
\text { government, municipalities not } \\
\text { included }\end{array}$ \\
\hline Independent living & Supported through state funding & $\begin{array}{l}\text { Supported mostly through } \\
\text { NGO funding }\end{array}$ & $\begin{array}{l}\text { Supported through state funding, } \\
\text { exceptions for certain groups. } \\
\text { Traditionally people live with } \\
\text { their families. }\end{array}$ & Supported through state funding \\
\hline Education & $\begin{array}{c}\text { Education within mainstream } \\
\text { schools favoured in most states, } \\
\text { higher education needs to cater for } \\
\text { students with disabilities }\end{array}$ & $\begin{array}{l}\text { Choice between mainstream and } \\
\text { special needs schools, higher } \\
\text { education needs to cater for } \\
\text { students with disabilities }\end{array}$ & $\begin{array}{l}\text { Education within mainstream } \\
\text { schools, higher education needs to } \\
\text { cater for students with disabilities. }\end{array}$ & $\begin{array}{l}\text { Education within mainstream schools } \\
\text { favoured, but special needs schools } \\
\text { available, higher education needs to } \\
\text { cater for students with disabilities }\end{array}$ \\
\hline Employment & $\begin{array}{c}\text { Discrimination prohibited, } \\
\text { employment quotas and fines for } \\
\text { not meeting them, state subsidies } \\
\text { for workplace adaptations, AT and } \\
\text { personal assistance }\end{array}$ & $\begin{array}{l}\text { Discrimination prohibited, state } \\
\text { subsidies for workplace adaptations, } \\
\text { tax allowances for employing } \\
\text { people with disabilities }\end{array}$ & $\begin{array}{l}\text { Discrimination prohibited, quotas, } \\
\text { state subsidies for workplace } \\
\text { adaptations }\end{array}$ & $\begin{array}{c}\text { Discrimination prohibited, state } \\
\text { subsidies for workplace adaptations, } \\
\text { AT and personal assistance, option of } \\
\text { wage subsidies }\end{array}$ \\
\hline
\end{tabular}




\section{Appendix B}

Table A2. List of experts interviewed.

\begin{tabular}{|c|c|c|}
\hline Country & Name & Affiliation \\
\hline Germany & Prof. Felix Welti & Institute of Social Welfare, University of Kassel, Kassel \\
\hline Hungary & Dr. Miklos Gyori & $\begin{array}{l}\text { Institute for the Psychology of Special Needs, Faculty of } \\
\text { Special Education, ELTE University, Budapest }\end{array}$ \\
\hline Portugal & Dr. Paula Pinto & $\begin{array}{l}\text { School of Social and Political Sciences, Technical University } \\
\text { of Lisbon, Lisbon }\end{array}$ \\
\hline \multirow[t]{2}{*}{ Sweden } & Prof. Berth Danermark & $\begin{array}{l}\text { Örebro University, School of Health Sciences, The Swedish } \\
\text { Institute for Disability Research, Örebro }\end{array}$ \\
\hline & Sofia Karlsson & $\begin{array}{c}\text { Swedish Disability Federation (Handikappförbunden } \\
\text { Sweden), Sundbyberg }\end{array}$ \\
\hline
\end{tabular}

\section{Appendix C-Interview Guide}

1. General Situation

1.1. How would you assess the overall social system in your country regarding persons with disabilities?

1.2. How well does the current legislative framework meet the needs of persons with disabilities?

- What could be improved?

- What has worked well and should remain as it is?

- How does it compare to the rest of the EU/or specific European countries?

2. The United Nations Convention on the Rights of Persons with Disabilities (CRPD)

2.1. To what extent has the implementation of the CRPD been successful in your country?

- What could be improved?

- What have been the major changes in your country because of/since the implementation of the CRPD?

- Have different stakeholders (e.g., patient organisations) been sufficiently involved in this process? If not, how could their involvement be improved?

3. The European Accessibility Act (EAA)

3.1. To what extent will the implementation of the EAA bring benefits for persons with disabilities in your country?

4. Assistive Technologies (ATs)

4.1. Are there enough financial funds and instruments available to cover the needs of persons with disabilities who require ATs and equipment?

- If not, what would be needed (e.g., further financial means, improved availability of/access to ATs)?

- Who is responsible for providing different ATs for persons with disabilities? How well does this work?

- How does the situation compare to the rest of the EU or specific European countries?

5. Public spaces

5.1. How would you rate the situation regarding accessibility to public spaces such as transport or ICT?

- In which areas has sufficient accessibility been achieved and what role have ATs played in this? 
- Where do you see the need for improvements and what would need to be done at policy level?

6. Independent living

6.1. To what extent is the social system meeting the needs of persons with disabilities in supporting their independent living? What role do ATs play?

- What works well? Could you give some examples of good practices?

- If not, what should be changed at policy level to improve the situation?

7. Education

7.1. How would you rate the education system in your country with regards to meeting the needs of pupils/students with disabilities?

- How well are different ATs used to facilitate the learning process at schools/universities?

- What role has regulation played in this situation?

8. Employment

8.1. How would you rate the situation of persons with disabilities regarding employment and in the workplace in your country? Are companies open to employing persons with disabilities and catering for their needs?

- If yes, what have been the main policy instruments supporting this trend?

- If not, which policy measures could facilitate an increased employment of persons with disabilities?

Do you have any additional questions and comments about the topic that we did not touch upon? Thank you!

\section{References}

1. United Nations. Convention on the Rights of Persons with Disabilities. 2006. Available online: https://www.un.org/development/desa/disabilities/convention-on-the-rights-of-persons-with-disabilities/ convention-on-the-rights-of-persons-with-disabilities-2.html/ (accessed on 15 September 2020).

2. Pascoe, E.; Smart Richman, L. Perceived Discrimination and Health: A Meta-Analytic Review. Psychol. Bull. 2009, 135, 531-554. [CrossRef]

3. Green, S.; Davis, C.; Karshmer, E.; Marsh, P.; Straight, B. Living Stigma: The Impact of Labeling, Stereotyping, Separation, Status Loss, and Discrimination in the Lives of Individuals with Disabilities and their Families. Sociol. Inq. 2005, 75, 197-215. [CrossRef]

4. World Health Organization. Priority Assistive Product List. 2016. Available online: https://apps.who.int/iris/bitstream/handle/10665/207694/WHO_EMP_PHI_2016.01_eng.pdf;jsessionid= 0585B6A7BCC808623231730A2F937000? sequence $=1$ (accessed on 15 September 2020).

5. Lansdown, G. See Me, Hear Me: A Guide to Using the UN Convention on the Rights of Persons with Disabilities to Promote the Rights of Children; Save the Children: London, UK, 2009.

6. European Union Agency for Fundamental Rights. Legal Capacity of Persons with Intellectual Disabilities and Persons with Mental Health Problems. Available online: https://fra.europa.eu/sites/ default/files/legal-capacity-intellectual-disabilities-mental-health-problems-factsheet-en_0.pdf (accessed on 15 September 2020).

7. ANED. Academic Network of European Disability Experts. Available online: http://www.disability-europe. net/ (accessed on 15 September 2020). 
8. European Commission. Evaluation of the European Disability Strategy 2010-2020. Available online: https://ec.europa.eu/social/main.jsp?langId=en\&atId=1484\&eventsId=1460\&furtherEvents=yes (accessed on 15 September 2020).

9. European Commission on Industry. Mandate to the European Standards Bodies for Standardization in the Field of Information and Communications Technologies (ICT) for Disabled and Elderly People. [Online]. 1998. Available online: http://ec.europa.eu/growth/tools-databases/mandates/index.cfm;jsessionid= 3F297B5DE35C774FD816D346B098E85B.cfusion46503?fuseaction=titSearch.main\&CFID=29486\&CFTOKEN= 806ae75eabc6dea3-3BCD69A9-C29D-DB03-318E76D614DBE759 (accessed on 15 September 2020).

10. European Commission on Enterprise and Industry. Standardisation Mandate to CEN, CENELEC and ETSI in Support of European Accessibility Requirements for Public Procurement of Products and Services in the ICT Domain; European Commission: Brussels, Belgium, 2005.

11. Court of Justice of the European Union. The EU, Acting on Its Own, may Conclude the Marrakesh Treaty on Access to Published Works for Persons Who Are Visually Impaired; Press Release No 13/17: Luxembourg, Luxembourg, 2017.

12. Statistisches Bundesamt [German Federal Office of Statistics]. Schwerbehinderte in Deutschland [Severely Disabled People in Germany]. Available online: https://www-genesis.destatis.de/genesis/online/ data;sid=EFBE41744CCBB6E4C49A937DE70804FB.GO_1_4?operation=statistikenVerzeichnisNextStep\& levelindex=0\&levelid=1557475572307\&index=8\&structurelevel=3 (accessed on 15 September 2020).

13. NEAK. Aufgaben der Nationalkasse für Gesundheitsversicherung (Ungarisches Akronym: NEAK) [Tasks of the National Fund for Health Insurance (Hungarian Acronym: NEAK)]. Available online: http://www.neak. gov.hu/felso_menu/rolunk/kozerdeku_adatok/tevekenysegre_mukodesre_vonatkozo_adatok/a_szerv_ feladata_alaptevekenysege_es_hatarkore/ne_a_szerv_alaptevekenyege_feladata_es_hatarkore (accessed on 15 September 2020).

14. US Social Security Administration. Social Security Programs throughout the World: Hungary. Available online: https://www.ssa.gov/policy/docs/progdesc/ssptw/2018-2019/europe/hungary.pdf (accessed on 15 September 2020).

15. Instituto Nacional de Estatistica. Censos 2011-Resultados Definitivos; Instituto Nacional de Estatitica: Lisboa, Portugal, 2012.

16. Simões, J.D.A.; Augusto, G.F.; Hernández-Quevedo, C. Portugal: Health System Review No. 2; European Observatory on Health Systems and Policies: Copenhagen, Denmark, 2017.

17. European Commission. Sweden-Benefits for People with Disabilities. Available online: https://ec.europa. eu/social/main.jsp?catId=1130\&langId=en\&intPageId=4813 (accessed on 15 September 2020).

18. United Nations. Convention on the Rights of Persons with Disabilities and Optional Protocol. [Online]. 2006. Available online: http://www.un.org/disabilities/documents/convention/convoptprot-e.pdf (accessed on 15 September 2020).

19. UNHCR. The Response of the Hungarian Government to the UN Special Rapporteur's Questionnaire on the Right of Persons with Disabilities to Participation in Decision Making. Available online: http://www. ohchr.org/Documents/Issues/Disability/DecisionMaking/States/PM\%20-\%20Hungary_ENG.doc (accessed on 15 September 2020).

20. United Nations Committee on the Rights of Persons with Disabilities. List of Issues in Relation to the Initial Report of Germany; United Nations: Geneva, Switzerland, 2014.

21. German State Party. Replies of Germany to the List of Issues in Relation to the Initial Report of Germany on the UN CRPD; United Nations: Geneva, Switzerland, 2015.

22. Aichele, V.; Bernot, S.; Hübner, C.; Kroworsch, S.; Leisering, B.; Litschke, P.; Palleit, L.; Pöllmann, K.; Striek, J. Wer Inklusion will, sucht Wege-Zehn Jahre UN-Behindertenrechtskonvention in Deutschland [eng. Ten years of UN CRPD in Germany]; Deutsches Institut für Menschenrechte [eng. German Insitute of Human Rights]: Berlin, Germany, 2019.

23. Hungarian Disability Caucus. Additional information about Hungary's compliance with the UN Convention on the Rights of Persons with Disabilities, with respect to the List of Issues and Replies from the Government of Hungary to the List of Issues. [Online]. 2012. Available online: http://adapt.it/adapt-indice-a-z/wpcontent/uploads/2014/08/UN_report_disabled_2012.pdf (accessed on 26 March 2019).

24. Observatório da Deficiência e Direitos Humanos. Parallel Report about the Monitoring of the Rights of Persons with Disabilities in Portugal; Observatório da Deficiência e Direitos Humanos: Lisbon, Portugal, 2015. 
25. United Nations. Concluding Observations on the Initial Report of Portugal; United Nations: Geneva, Switzerland, 2016.

26. The Swedish Disability Federation. Swedish Disability Movement's Alternative Report to the UN Committee on the Rights of Persons with Disabilities. [Online]. 2011. Available online: http://funktionsratt.se/wpcontent/uploads/2017/11/CRPD-Alternative-Report-Sweden.pdf (accessed on 15 September 2020).

27. Della Fina, V.; Cera, R. Protecting the Rights of People with Autism in the Fields of Education and Employment. International, European and National Perspectives; Springer: Heidelberg, Germany; New York, NY, USA; Dodrecht, The Netherlands; London, UK, 2015.

28. European Union Agency for Fundamental Rights. Legal Capacity of Persons with Intellectual Disabilities and Persons with Mental Health Problems. Available online: https://fra.europa.eu/sites/default/files/legalcapacity-intellectual-disabilities-mental-health-problems.pdf (accessed on 15 September 2020).

29. Wallgren, J. Gode Mannens ABC: Handbok för Gode Män och Förvaltare [eng. Handbook for Trustees], 3rd ed.; Wolters Kluwer: Alphen aan den Rijn, The Netherlands, 2017.

30. Bundesverfassungsgericht [eng. German Federal Constitutional Court]. Wahlrechtsauschlüsse für Betreute in Allen Angelegenheiten und Wegen Schuldunfähigkeit Untergebrachte Straftäter Verfassungswidrig. Pressemitteilung Nr. 13/2019. [Online]. 21 February 2019. Available online: https: //www.bundesverfassungsgericht.de/SharedDocs/Pressemitteilungen/DE/2019/bvg19-013.html (accessed on 15 September 2020).

31. FRA. Accessible Polling Stations-Indicators on Political Participation of Persons with Disabilities. Available online: https://fra.europa.eu/en/publication/2014/indicators-right-political-participation-people-disabilities/ polling-stations (accessed on 15 September 2020).

32. Deutscher Gehörlosen-Bund e.V. [eng. German Association of the Deaf]. Hörbehinderte Kinder an Regelschulen: Was für den Erfolgreichen Besuch einer Regelschule Wichtig ist [eng. Hearing Impaired Children in Mainstream Schools: What It Takes to Succeed]. [Online]. 2016. Available online: http://www.gehoerlosen-bund.de/index.php?option=com_content\&view=article\&id=1561\% 3Ahoerbehindertekinderanregelschulenwasfuerdenerfolgreichenbesucheineregelschulewichtigist\&catid= 83\%3Ameinkind\&Itemid=129\&lang=de (accessed on 15 September 2020).

33. Hungarian Association of the Deaf and Hard of Hearing. KONTAKT Tolmácsszolgalat [eng. KONTAKT Interpreting Services]. [Online]. 2019. Available online: https://sinosz.hu/sinosz-materials-in-english// (accessed on 15 September 2020).

34. Specialpedagogiska Skolmyndigheten [Swedish Special Needs Education School Authority]. Special Needs Schools. Available online: https://www.spsm.se/om-oss/other-languages/english/our-mission/ (accessed on 15 September 2020).

35. BMAS-Bundesministerium für Arbeit und Soziales [eng. German Federal Ministry of Labour and Social Affairs]. Entwurf eines Gesetzes zur Weiterentwicklung des Behindertengleichstellungsrechts [eng. Draft on the Revision of the Law for the Equality of Disabled People]. [Online]. 2016. Available online: http: //www.bmas.de/SharedDocs/Downloads/DE/PDF-Meldungen/2016/gesetzentwurf-zur-weiterentwicklungdes-behindertengleichstellungsrechts.pdf;jsessionid=D616BD3F6A2D959CF7D244B7DA2149AD?_blob= publicationFile\&v=3 (accessed on 15 September 2020).

36. Swedish Institute. Facts about Sweden-Disability Policy. [Online]. 2016. Available online: https: //sharingsweden.se/materials/swedens-disability-policy/ (accessed on 15 September 2020).

37. Chadwick \& Wesson. Digital Inclusion and Disability. In Attrill \& Fullwood: Applied Cyberpsychology: Practical Applications of Cyberpsychological Theory and Research; Palgrave Macmillan: London, UK, 2016; pp. 1-23.

38. European Commission on Information Society and Media. Monitoring eAccessibility. [Online]. 2011. Available online: http://www.eaccessibility-monitoring.eu/researchResult.aspx (accessed on 15 September 2020).

39. Landesarbeitsgericht Niedersachsen [eng. State Labour Court of Lower Saxony]. Decision on the 6th of December 2010, 12 Sa 860/10. [Online]. Available online: https://openjur.de/u/326297.html (accessed on 15 September 2020).

40. Bábel, B.; Kiss, A. Case Study -Hungary - Supporting industrial relations in the field of work adaptation to enable the employment of older or disabled population. [Online]. 2017. Available online: http://www.praxis. ee/wp-content/uploads/2016/04/IR-WA-Case-Study-Hungary2017.pdf (accessed on 15 September 2020). 
41. European Commission. Infringement Procedure. Available online: https://ec.europa.eu/info/law/lawmaking-process/applying-eu-law/infringement-procedure_en (accessed on 15 September 2020).

42. European Commission. Monitoring the Application of Union Law: 2018 Annual Report. Available online: https://ec.europa.eu/info/sites/info/files/report-2018-annual-report-monitoring-application-eu-law. pdf (accessed on 15 September 2020).

43. Martinez-Pujalte, A. Legal Capacity and Supported Decision-Making: Lessons from Some Recent Legal Reforms. Laws 2019, 8, 4. [CrossRef]

(C) 2020 by the authors. Licensee MDPI, Basel, Switzerland. This article is an open access article distributed under the terms and conditions of the Creative Commons Attribution (CC BY) license (http://creativecommons.org/licenses/by/4.0/). 